\title{
The Social Safety Nets and Poverty Alleviation in Pakistan: An Evaluation of Livelihood Enhancement and Protection Programme
}

\author{
Asif Javed, Vaqar Ahmed ${ }^{2}$, Bakhrul Khair Amal ${ }^{3}$ \\ 1,2Sustainable Development Policy Institute (SDPI), Pakistan \\ ${ }^{3}$ Universitas Negeri Medan, Indonesia \\ Email: asifjaved@sdpi.org, b4khrul.4m41@gmail.com
}

\begin{abstract}
:
Sustainable Development Goal (SDG) 1 intends to end poverty of all forms and the government of Pakistan is also targeting poverty alleviation through social safety nets. 'Ehsaas' is the major social safety nets proramme which include various initiatives that are benefiting millions of households. The study examines the state of poverty in Pakistan and also highlights the spending under each social safety net. Furthermore, the study also evaluates the Livelihood Enhancement and Protection (LEP) programme which is a major initiative for poverty alleviation under Ehsaas programme. Survey in Khyber Pakhtunkhawa and Balochistan provinces were conducted of those beneficiaries who are getting asset and skills training. It was found that asset provision and skills trainings are helpful in increasing the earnings and provide sustainable livelihood opportunities to poor households.
\end{abstract}

\section{Keywords:}

poverty; social safety nets; asset transfer; skills training; livelihood

\section{Introduction}

According to Cost of Basic Needs (CBN) method which is official measure of poverty in Pakistan, 24.3\% people were living below poverty line in 2015-16 (Economic Survey of Pakistan). To tackle the issue, government is committed to follow Sustainable Development Goal-1 which aims to 'end poverty in all its forms everywhere' and as per national definitions, it is intended to decrease at least half the proportion of population from poverty in all dimensions by 2030. United Nations also proclaimed that social protection is helpful in achieving SDG 1 through reducing poverty and providing a safety net for the vulnerable. Government of Pakistan initiated targeted interventions from time to time in which Benazir Income Support Programme (BISP) and Ehsaas programme are major social safety nets programmes. Social protection policies are significant for developing employment prospects and helping people to graduate out of poverty levels (Khan, 2013).

Safety nets are special initiated measures based upon food support, cash transfer, social welfare and employment programs targeting people who are below poverty level (Nasim, 2014). Incidences of poverty are higher in South Asian region as high level of economic growth could not assist in welfare improvement for the poor. During 2010-17, Gini coefficient has increase for all South Asian countries which demonstrates the incidences of greater inequality (South Asia Inequality Report, 2019). 
Table 1. Multidimensional Poverty in South Asia

\begin{tabular}{|c|c|c|c|}
\hline \multirow[t]{2}{*}{ Country } & \multirow{2}{*}{$\begin{array}{c}\text { Population living } \\
\text { below income poverty } \\
\text { line }(\%)\end{array}$} & \multicolumn{2}{|c|}{ Population in multidimetional poverty } \\
\hline & & $\begin{array}{l}\text { Headcount } \\
\text { (thousands) }\end{array}$ & $\begin{array}{c}\text { Population vulnerable to } \\
\text { multidimentional poverty (\%) }\end{array}$ \\
\hline Afghanistan & 54.5 & 19,865 & 18.1 \\
\hline Bangladesh & 24.3 & 68,663 & 21.4 \\
\hline India & 21.9 & 373,735 & 19.3 \\
\hline Maldives & 8.2 & 3 & 4.8 \\
\hline Nepal & 25.2 & 9,961 & 22.3 \\
\hline Pakistan & 24.3 & 75,520 & 12.9 \\
\hline
\end{tabular}

Source: UNDP Human Development Report, 2019

Table 1 sheds light on the poverty incidences in South Asia and it can be observed that $12.9 \%$ population in Pakistan is vulnerable to multidimentional poverty while $24.3 \%$ population is living below poverty line. Nepal has the highest percentage of population vulnerable to multidimentional poverty while Afghanistan has the highest percentage of population living below poverty line.

The government of Pakistan has recently initiated National Poverty Graduation Initiative (NPGI) under the flagship Poverty Alleviation Programme 'Ehsass'. The programme will be implemented in a time period of six years covering 23 districts and 375 union councils across the country. The major components of the initiatives include asset transfers, vocational and skills training and interest free loans.

The main objectives of the study are; to examine the spending under existing social safety nets programmes and to evaluates the impact of asset transfers and vocational and skills training on the poverty reduction. For the purpose, survey of beneficiaries of these programmes was conducted in provinces of Khyber Pakhtunkhawa and Balochistan. Two districts in Khyber Pakhtunkhawa and three districts in Balochistan were selected for the field survey.

Section two is based on literature review while section three discusses the state of poverty in Pakistan. Section four highlights the social safety nets and the section five is based on Livelihood Enhancement and Protection programme. Section 6 explains the methodology of the study and the last section discusses the conclusion and policy recommendations.

\section{Review of Literatures}

Well designed and well-targeted social transfer programs are prove to be an affordable and effective measure to tackle the poverty among households along with improvement in health and education of children (Cecchini and Madariaga, 2011). Fiszbein et al. (2009) also pointed out the same view that cash transfers can reach the poorest in a more beneficial way through effective targeting. Cash transfers resolve the liquidity issue of poorest household which may promote the entrepreneurship among them (McKenzie and Woodruff, 2006). Cash transfers in Latin America introduce the conditions regarding human development which includes health checks and school attendance and this helped in better nutritional levels among children and better attendance at school (Fiszbein et al. 2009). 
Mexico's Prospera provides employment training and income-generating prospects and also subsidized childcare (Holmes \& Jones, 2013) while same kind of initiatives were taken in Bolsa Familia programme in Brazil (Fultz and Francis, 2013). Wallenborn (2009) found that skills training helped in improving ability and knowledge to process local agriculture products in Tajikistan. World Bank (2007) stated that the vocational education helps in resolving employment crisis especially for new workers. University education also plays a key role in grooming of youth (Sakir and Hasso, 2020). Education counseling programs can minimize the academic difficulties of students and provide them relief from social distance, emotion management and isolation which is affecting the student performance during Covid-19 (Korea, 2020).

Domestic market reforms in Pakistan are also required at district and sub district level for which firms can play their part through establishing their own training institutes where desired skills for students can be provided (Haque et al. 2011). Hoddinott (2008) examined that safety net programs contributed towards agriculture and economic growth by their impact on asset creation and protection. Asset transfer program in Bangladesh brings forth positive results to mitigate poverty among poorest households (Krishna et al. 2014). Sule and Sambo (2020) suggested that conditional cash transfer, small scale industrialization, promoting agriculture sector and youth empowerment schemes can play a significant role in poverty alleviation.

Ahmed et al. (2009) examined that the transfer of livestock and poultry assets increased the earnings of the beneficiaries while also positively influence the saving behavior of beneficiaries in Bangladesh. The study also pointed out that the asset transfer also helps in generates further productive assets for the households. Ahmed and Javed (2016) mentioned that livestock assets provides milk and meat which helps in enhancing nutrition level. Several programmes in India were also launched for poverty eradication through asset provision and wage employment particularly for poor households in rural areas (Selvaraj, 2011). Households which have productive assets are more likely to graduate out of poverty (Carter and May, 2001).PPAF (2014) examined that asset transfer to ultra-poor under LEP program increased the prospects of earnings for them while the asset value also increases over the time period.

\subsection{State of Poverty in Pakistan}

Planning Commission of Pakistan estimated the poverty bands at national and regional levels in Pakistan. Poverty prevails more in rural region as compared to urban region, Ashraf (2017) also pointed out that poverty is more severe in rural areas on which government should pay more attention. Poor governance resulted in inefficient provision of social services while slower economic growth is also cause poverty in Pakistan (ADB, 2002). Considering the poverty level, government of Pakistan initiated social safety nets and increased the allocations under the programmes.

Table 2. Poverty Bands at National and Regional Level in Pakistan

\begin{tabular}{|c|c|c|c|c|c|c|}
\hline \multirow{2}{*}{ Poverty bands } & \multicolumn{3}{|c|}{ Percentage of population } & \multicolumn{3}{c|}{$\begin{array}{c}\text { Estimated head counts } \\
\text { (Millions) }\end{array}$} \\
\cline { 2 - 7 } & National & Urban & Rural & National & Urban & Rural \\
\hline $\begin{array}{c}\text { Extreme Poor }(<50 \% \\
\text { of Poverty Line) }\end{array}$ & 0.42 & 0.21 & 0.54 & 0.83 & 0.24 & 0.42 \\
\hline $\begin{array}{c}\text { Ultra Poor }>50 \% \text { and } \\
<75 \% \text { of Poverty Line) }\end{array}$ & 6.00 & 2.39 & 7.95 & 11.73 & 2.81 & 6.19 \\
\hline $\begin{array}{c}\text { Poor }>75 \% \text { and }< \\
100 \% \text { of Poverty Line) }\end{array}$ & 17.89 & 9.93 & 22.18 & 34.96 & 11.66 & 17.29 \\
\hline
\end{tabular}




\begin{tabular}{|c|c|c|c|c|c|c|}
\hline $\begin{array}{c}\text { Vulnerable }(>100 \% \\
\text { and }<125 \% \text { of Poverty } \\
\text { Line) }\end{array}$ & 19.87 & 14.46 & 22.78 & 38.83 & 16.99 & 17.75 \\
\hline $\begin{array}{c}\text { Quasi Non-Poor }(> \\
\begin{array}{c}125 \% \text { and }<200 \% \text { of } \\
\text { Poverty Line) }\end{array}\end{array}$ & 34.77 & 37.68 & 33.21 & 67.95 & 44.27 & 25.88 \\
\hline $\begin{array}{c}\text { Non-Poor }>200 \% \text { of } \\
\text { Poverty Line) }\end{array}$ & 21.04 & 35.33 & 13.34 & 41.10 & 41.50 & 10.40 \\
\hline
\end{tabular}

Source: National Poverty Report 2015-16 (Planning Commission of Pakistan)

Poverty bands explain population description into different bands which require different policy measures. It can be examined from the table that $6.4 \%$ of population of Pakistan (12.6 million) requires social safety net coverage because this number of population comes under extreme and ultra-poor category (Table 2 ). $17.9 \%$ population (35 million) is on the border line whereas $19.9 \%$ (38.8 million) is vulnerable population for whom negative shock can bring them below poverty line. Protecting these millions of people from vulnerable situation and graduating them out of poverty required extensive allocations under social safety nets.

Table 3. Multidimentional Poverty by Province

\begin{tabular}{|l|c|c|c|}
\hline Province & MPI & Incidence & Intensity \\
\hline Punjab & 0.152 & $31.4 \%$ & $48.4 \%$ \\
\hline Sindh & 0.231 & $43.1 \%$ & $53.5 \%$ \\
\hline Khyber Pakhtunkhawa & 0.250 & $49.2 \%$ & $50.7 \%$ \\
\hline Balochistan & 0.394 & $71.2 \%$ & $55.3 \%$ \\
\hline
\end{tabular}

Source: Ministry of Planning

The table 3 indicates that the multidimentional poverty is highest in Balochistan while Khyber Pakhtunkhawa is at the second in terms of poverty. Based upon the higher level of poverty in Balochistan and Khyber Pakhtunkhawa, the study selected these two provinces for examining the impact of asset transfer and skills training on the economic situation of those who attained them. Pasha and Kardar (2020) pointed out that after COVID-19, the allocations under social protection and anti-poverty initiatives should be increase in order to protect the families going into poverty as large number of daily wage and causal workers are affected . It is estimated that millions of people may face unemployment due to COVID-19 crisis (Javed, 2020a).

Table 4. Multidimentional Poverty by District

\begin{tabular}{|l|c|c|c|c|}
\hline Province & District & MPI & Incidence & Intensity \\
\hline Khyber Pakhtunkhawa & Chitral & 0.194 & $44.3 \%$ & $44.9 \%$ \\
\cline { 2 - 5 } & Upper Dir & 0.443 & $76.4 \%$ & $58.0 \%$ \\
\hline \multirow{3}{*}{ Balochistan } & Lasbela & 0.395 & $68.1 \%$ & $58.0 \%$ \\
\cline { 2 - 5 } & Pishin & 0.453 & $82.2 \%$ & $55.1 \%$ \\
\cline { 2 - 5 } & Zhob & 0.514 & $82.8 \%$ & $62.1 \%$ \\
\hline
\end{tabular}

Source: Ministry of Planning

The study selected the Chitral and Upper Dir districts in Khyber Pakhtunkhawa and Lasbela, Pishin and Zhob districts in Balochistan for examining the impact of asset transfer and skills training. In our selected districts the poverty incidence is highest in Zhob as compared to other districts (Table 4). Except Chitral, MPI is higher for every district as compared to their relative provincial figures. 


\subsection{Social Safety Nets}

Currently 'Ehsaas' is the major social safety net programme by the government of Pakistan.

\section{Ehsaas}

Several programmes are initiated under 'Ehsaas' program. Recently after the outspread of Coronavirus (COVID-19), government gave relief package of Rs. 144 billion in order to provide immediate cash relief of Rs. 12000 per household. This will be a four months package for around 12 million poor households of daily wage earners who are badly affected by the virus spread. Millions of workers are facing the threat of layoff in Pakistan due to pandemic spread and drop in economic activities.

Table 5. Ehsaas Emergency Cash Transfer

\begin{tabular}{|l|c|c|}
\hline \multicolumn{1}{|c|}{ Province } & $\begin{array}{c}\text { Total beneficiaries } \\
\text { served }\end{array}$ & $\begin{array}{c}\text { Total amount distributed (Rs. } \\
\text { Million) }\end{array}$ \\
\hline Punjab & $4,846,969$ & $58,738.9$ \\
\hline Sindh & $3,415,421$ & $41,204.9$ \\
\hline Khyber Pakhtunkhawa & $2,053,520$ & $24,924.2$ \\
\hline Balochistan & 570,498 & $6,936.9$ \\
\hline
\end{tabular}

Source: Poverty Alleviation and Social Safety Division

Ehsaas emergency cash transfer has distributed millions to deserving households while the total number of beneficiaries so far are more than 2 million in Khyber Pakhtunkhawa and 0.5 million in Balochistan (Table 5).

The two major programmes under Ehsaas are 'Ehsaas Kafaalat' and 'Ehsaas Amdan' programmes. 'Ehsaas Kafaalat' program aims to mitigate vulnerability and decreasing poverty. Under 'Ehsaas Kafaalat' programme cash stipends of Rs. 2000 monthly are given to poorest and deserving women across Pakistan. The programme is expected to target 7 million women beneficiaries in 70 districts and initially one million families were enrolled. These families started receiving stipends under the program from February to March 2020. Apart from cash transfer, Kafaalat program also targets financial inclusion of women through bank account under Prime Minister's 'One Women One Bank Account' initiative. Women will have access to smartphones which will help in digital inclusion and gradual recovery from poverty.

Ehsaas Amdan' programme started in January 2020 and it is a four year programme which will end in 2023. The programme is designed to promote livelihoods and jobs. Assets including livestock, transport vehicle parts, inputs for small retail outlets and micro enterprises and agriculture inputs are being provided to the deserving households in order to graduate them out of poverty. Furthermore, beneficiaries are also supported through vocational training and Interest Free Loan where required. Currently the program is initiated in 23 poorest districts across the four provinces of Pakistan. The programme aimed to support around 1.4 million people across Pakistan in order to uplift them from poverty level. Through different programmes and spending, Ehsaas is supporting the economic empowerment and emphasizes on the poverty eradication.

\subsection{Livelihood Enhancement and Protection (LEP)}

LEP programme intends to uplift ultra and vulnerable households from poverty by providing vocational and skills training, asset transfer and interest-free loans. The target is to transfer livelihood assets and training to 176,877 vulnerable and ultra-poor households during the time period of six years. Rs. 2,043 million were distributed under LEP programme during July-Mar FY 20. 


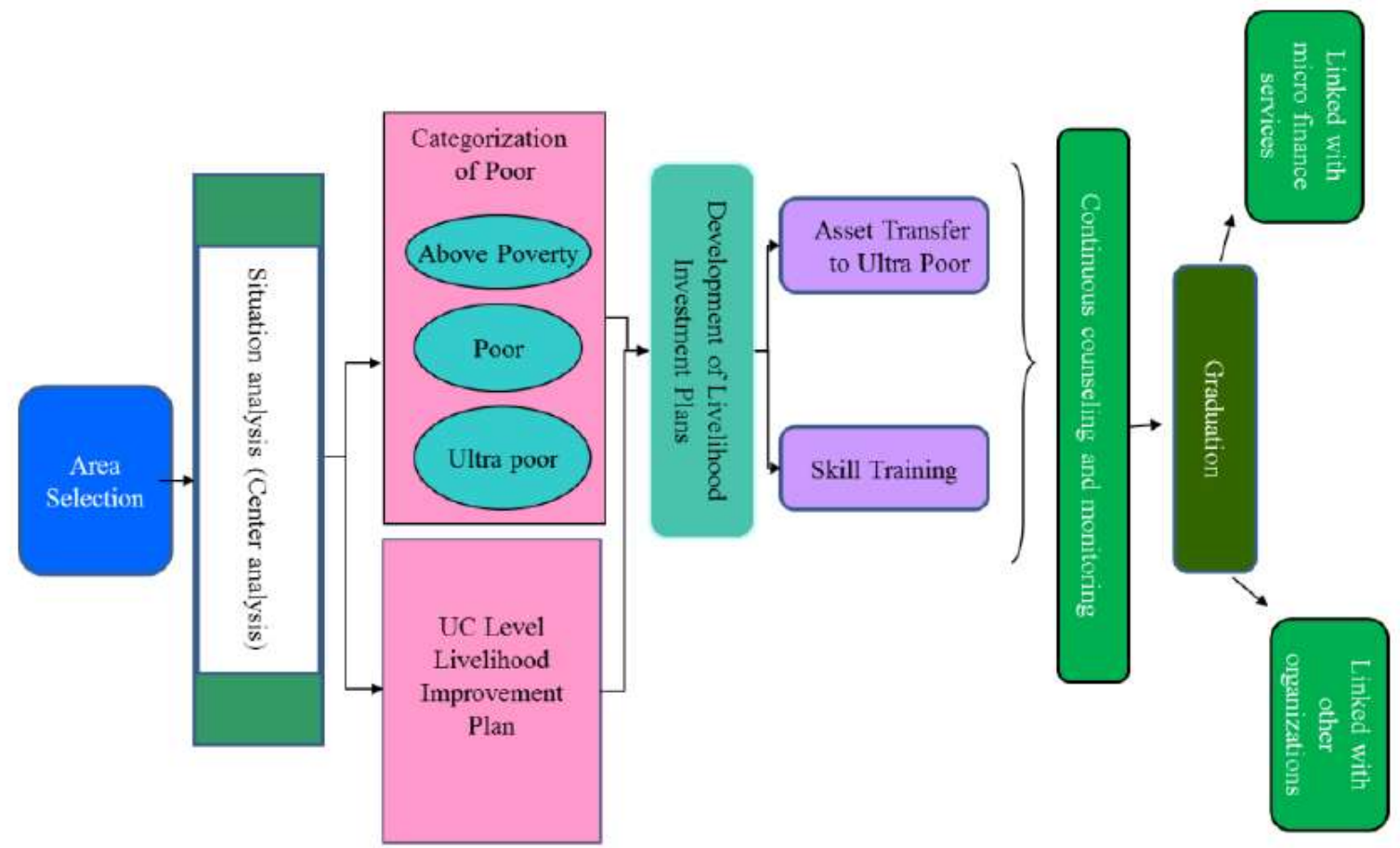

Figure 1. Conceptual Framework of LEP Model

Source: Pakistan Poverty Alleviation Fund, Final Report (2014)

Figure explains that there are three categories of poor which are above poverty, poor and ultra-poor. Livelihood improvement plan is being made at UC level through which asset transfer to ultrapoor and skill training are being provided.

Table 6. Transfers under LEP

\begin{tabular}{|l|c|c|}
\hline Year & Asset transfer & Skills training \\
\hline FY 18 & 1,424 & 1126 \\
\hline FY 19 & 556 & 2,310 \\
\hline FY 20 & 10,615 & 4,027 \\
\hline
\end{tabular}

Source: Economic Survey of Pakistan

During FY 20, asset transfer and skills training have increased significantly as total 10,615 assets were transferred while 4,027 skills trainings were given (Table 6).

\section{Research Methods}

Multistage stratified random sampling is used in the study which is a useful approach when we need to subdivide target population to minimize error. Balochistan and Khyber Pakhtunkhawa provinces were selected for the study based upon the higher poverty incidence in those two regions as compared to other provinces. In the two provinces, districts were selected based on regional and ethnicity coverage. Regional coverage was focused in Khyber Pakhtunkhawa for district selection while an ethnicity criterion was adopted for district selection in Balochistan. This is done to bring heterogeneity within in the sample. Furthermore, Union Councils (UCs) in these districts were selected based upon number of interventions and in these UCs, villages were selected with highest proportion based upon random sampling. Beneficiaries from these regions were selected through random sampling at $5 \%$ level of significance. Primary data was collected through survey for Livelihood Enhancement and Protection program which has two components. Survey of 307 
beneficiaries of asset transfer program were interviewed in 5 districts out of which 2 were from Khyber Pakhtunkhawa and 3 were from Balochistan. Survey of 326 beneficiaries of skills training was also conducted. The below table shows the sample covered at district level.

Table 7. District profile

\begin{tabular}{|c|c|c|c|c|c|c|c|}
\hline Province & Districts & $\begin{array}{l}\text { Populatior } \\
\text { (a) }\end{array}$ & $\begin{array}{l}\text { Primary } \\
\text { schools (b) }\end{array}$ & $\begin{array}{c}\text { Literacy (\%) } \\
\text { (c) }\end{array}$ & $\begin{array}{c}\text { Basic Health } \\
\text { Units (d) }\end{array}$ & $\begin{array}{l}\text { Dependency } \\
\text { ratio }(\%)(\mathrm{e})\end{array}$ & $\begin{array}{c}\text { Inadequate } \\
\text { ource of drinkin } \\
\text { water ( } \%) \\
\text { (f) }\end{array}$ \\
\hline \multirow{2}{*}{$\begin{array}{l}\text { Khyber } \\
\text { Pakhtunkhawa }\end{array}$} & Chitral & 447,362 & 494 & 62 & 19 & 66 & 17 \\
\hline & Upper Dir & 946,421 & 735 & 42 & 31 & - & 85 \\
\hline \multirow[t]{3}{*}{ Balochistan } & Lasbela & 574,292 & 508 & 42 & 42 & 68 & 54 \\
\hline & Pishin & 736,481 & 826 & 49 & 31 & 85 & 13 \\
\hline & Zhob & 310,544 & 298 & 43 & 15 & 96 & 69 \\
\hline
\end{tabular}

Source: (a) Population Cencus 2017, ( b) Development Statistics of Khyber Pakhtunkhawa 2019, Balochistan Education Statistics, (c) PSLM 2014-15, (d) Development Statistics of Khyber Pakhtunkhawa, PPAF, (e) PPAF, (f) PPAF

The table 7 explains the social statistics of the selected districts of Khyber Pakhtunkhawa and Balochistan. Dependency ratio is highest in Zhob while the ratio is also higher in other districts as well which shows that limited number of persons are involved in economic activities and are supporting their families. There is lack of basic necessities including health and water availability as existing Basic Health Units are not sufficient to provide health services to the regional population while the access towards clean drinking water is also an issue.

Table 8. Sampling distribution for LEP

\begin{tabular}{|c|c|c|c|c|c|c|}
\hline & \multicolumn{2}{|c|}{ Khyber Pakhtunkhawa } & \multicolumn{3}{|c|}{ Balochistan } & \multirow{2}{*}{ Total } \\
\cline { 1 - 6 } District & Upper Dir & Chitral & Pishin & Zhob & Lasbella & \\
\hline Asset provision & 58 & 22 & 27 & 96 & 105 & 307 \\
\hline Skills training & 97 & 30 & 28 & 83 & 88 & 326 \\
\hline
\end{tabular}

Total 80 beneficiaries in Khyber Pakhtunkhawa and 228 beneficiaries in Balochistan were interviewed for asset transfer program (Table 8). 127 beneficiaries in Khyber Pakhtunkhawa and 199 beneficiaries in Balochistan were interviewed for skills training. In Balochistan due to security concerns, some of the regions could not be visited. Alternatively the study conducted the survey in the nearby locations in these regions. 


\section{Results and Discussion}

Survey of 307 beneficiaries of asset provision and 326 beneficiaries of skills training were conducted. The major findings of the field survey are discussed below.

\subsection{Assets Provision}

Table 9. Asset Provision

\begin{tabular}{|c|c|c|c|c|c|c|}
\hline District & Livestock & Trading & Services & Production & Transport & Total \\
\hline Upper Dir & 27 & 7 & 9 & 8 & 6 & 57 \\
\hline Chitral & 6 & 9 & 4 & 2 & 1 & 22 \\
\hline Pishin & 23 & 2 & 1 & 0 & 1 & 27 \\
\hline Zhob & 82 & 5 & 4 & 4 & 1 & 96 \\
\hline Lasbela & 83 & 16 & 2 & 0 & 4 & 105 \\
\hline Total & 221 & 39 & 20 & 14 & 13 & 307 \\
\hline
\end{tabular}

Total $72 \%$ of the beneficiaries received livestock assets while $12.6 \%$ beneficiaries received trading assets (Table 9). 57.9\% of the beneficiaries were extremely satisfied with the provided asset while $35.6 \%$ beneficiaries were very satisfied. The major reason for their satisfaction is the increase in income which is made possible based on provided asset.

Table 10. Monthly household income (In PKR)

\begin{tabular}{|l|c|c|c|c|c|c|c|}
\hline & & $5,000-$ & $10,000-$ & $15,000-$ & $20,000-$ & $25,000-$ \\
25,000 & 30,000 & $\begin{array}{c}\text { More } \\
\text { than } \\
30,000\end{array}$ \\
\hline Upper Dir & $39.7 \%$ & $32.8 \%$ & $17.2 \%$ & $3.4 \%$ & $3.4 \%$ & $1.7 \%$ & $1.7 \%$ \\
\hline Chitral & $4.3 \%$ & $65.2 \%$ & $17.4 \%$ & $13.0 \%$ & - & - & - \\
\hline Pishin & $22.2 \%$ & $51.9 \%$ & $11.1 \%$ & $11.1 \%$ & $3.7 \%$ & $0.0 \%$ & - \\
\hline Zhob & $19.6 \%$ & $47.4 \%$ & $24.7 \%$ & - & $5.2 \%$ & $3.1 \%$ & - \\
\hline Lasbela & $26.7 \%$ & $42.9 \%$ & $25.7 \%$ & $1.9 \%$ & $1.9 \%$ & $1.0 \%$ & - \\
\hline
\end{tabular}

Most of the respondents (39.7\%) in Upper Dir are earning upto Rs. 5,000 (Table 10). 65.2\% respondents in Chitral and 51.9\% respondents in Pishin are earning within the range of Rs. 5,000-10,000 monthly.

95.8\% beneficiaries pointed out that the provided asset has helped in increasing their monthly earnings. It is significant for the households as $69.7 \%$ of the respondents were those who had monthly earnings of less than Rs.10000. Those who were holding livestock asset, informed that the asset has helped them in ensuring food and nutritional security. A female respondent said that the sewing machine helped her to work from home which also prompts her towards saving. Similarly, person who owned a grocery store received grocery items which helped increasing his daily sales. He is now spending the increased earnings on the education of his children. 


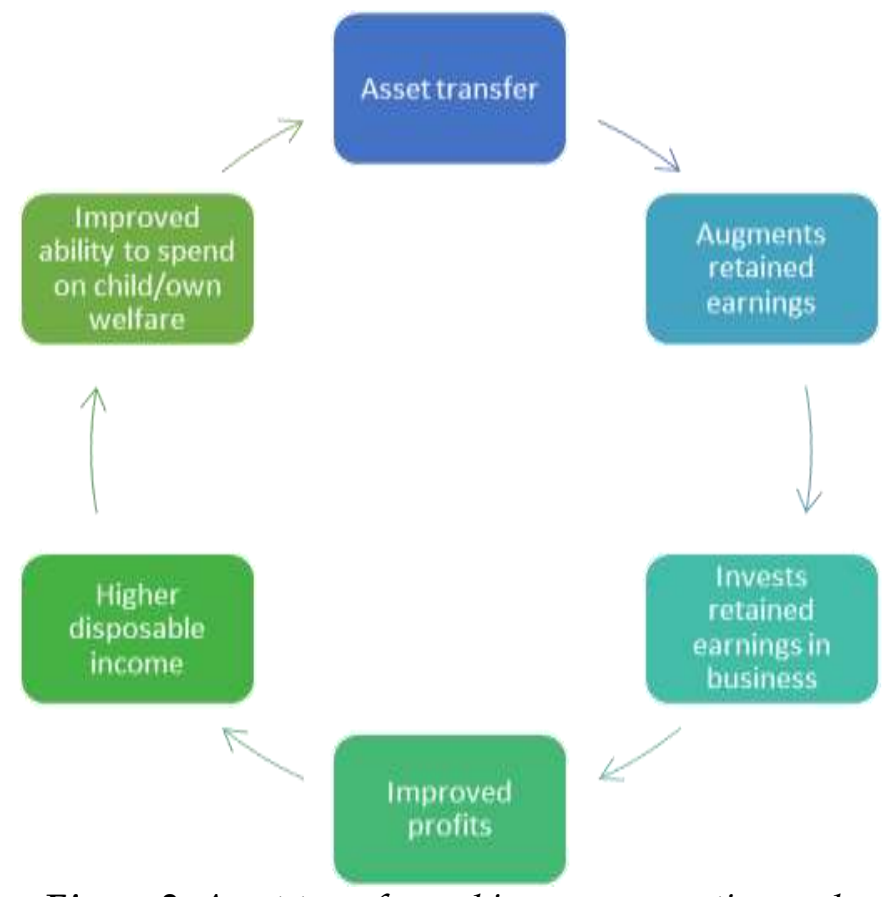

Figure 2. Asset transfer and income generation cycle

The figure 2 explains the channels through which asset transfer resulted in income generation. The figure explains that asset transfer helps in retaining earnings which is then being invested in business from where profit generation takes place. Through this, not only the higher profits are available to household but also the higher income levels increases the welfare level through more spending on health, education and food related expenditures.

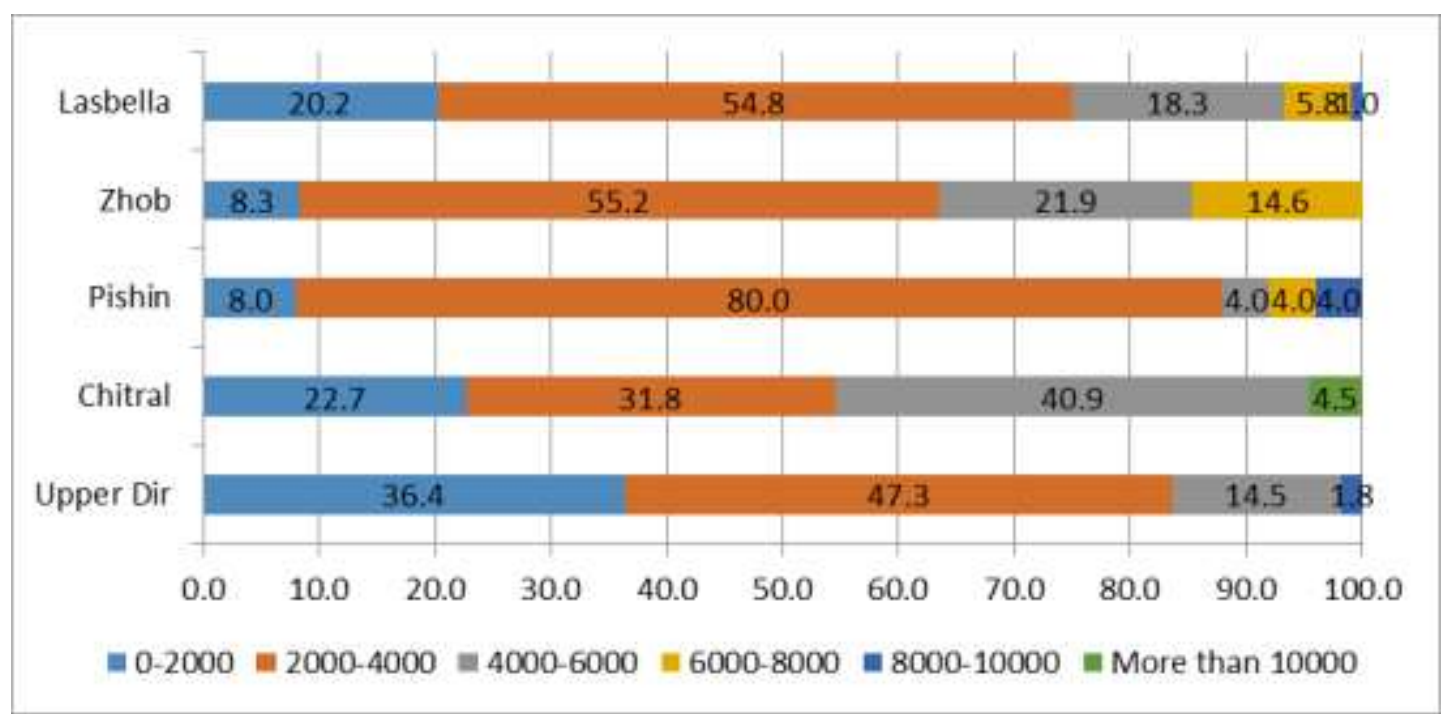

Figure 3. Increase in household income (in PKR)

Total 54\% respondents pointed out that their monthly income increased in a range of Rs.2000-4000 due to asset transfer (Figure 3). Out of total respondents in Zhob, income of $14.6 \%$ respondents increased within the range of Rs.6000-8000, while 40.9\% respondents out of total in Chitral reported their monthly income increase within the range of Rs.4000-6000. 


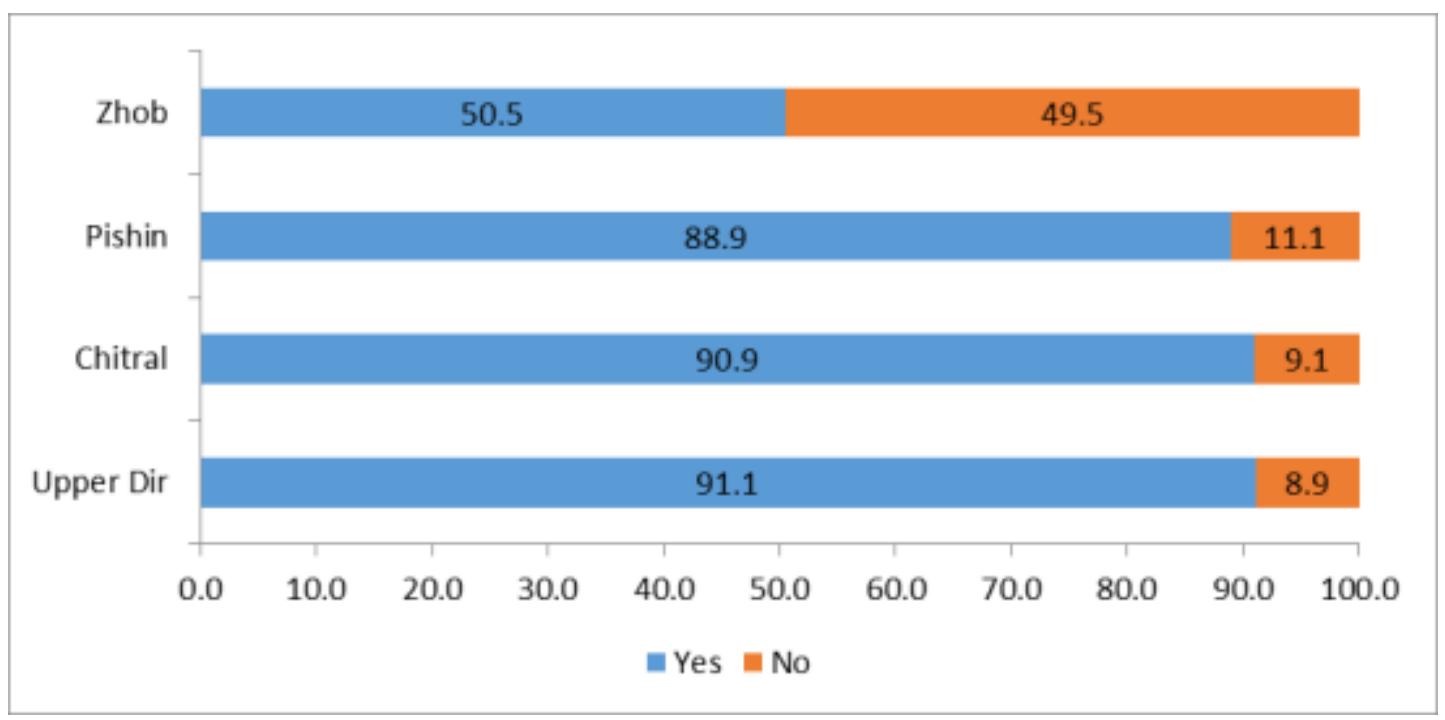

Figure 4. Increase in asset base

$71.1 \%$ respondents informed that the provided asset has helped in increasing their asset base and which resulted further increase in income (Figure 4). The highest percentage of asset base increase was reported in Upper Dir where 91.1\% respondents said that their asset base increase.

\subsection{Skills Training}

Table 11. Monthly household income

\begin{tabular}{|c|c|c|c|c|c|c|c|}
\hline & $0-5,000$ & $5,000-10,000$ & $10,000-15,000$ & $15,000-20,000$ & $20,000-25,000$ & $25,000-30,000$ & $\begin{array}{c}\text { More than } \\
30,000\end{array}$ \\
\hline Upper Dir & $48.5 \%$ & $19.6 \%$ & $14.4 \%$ & $10.3 \%$ & $4.1 \%$ & $2.1 \%$ & $1.0 \%$ \\
\hline Chitral & $26.7 \%$ & $43.3 \%$ & $13.3 \%$ & $10.0 \%$ & $3.3 \%$ & - & $3.3 \%$ \\
\hline Pishin & $21.4 \%$ & $50.0 \%$ & $14.3 \%$ & $14.3 \%$ & - & - & - \\
\hline Zhob & $25.3 \%$ & $44.6 \%$ & $20.5 \%$ & - & $7.2 \%$ & $2.4 \%$ & - \\
\hline Lasbela & $31.8 \%$ & $34.1 \%$ & $25.0 \%$ & $5.7 \%$ & $2.3 \%$ & - & $1.1 \%$ \\
\hline
\end{tabular}

The respondents are earning marginal income as 48.5\% respondents in Upper Dir and $31.8 \%$ respondents in Lasbela are earning up to 5,000 monthly income (Table 11). 50\% respondents in Pishin and 44.6\% respnodents in Zhob are earning around 5,000-10,000 monthly. This depicts that people are living on subsistence income. 


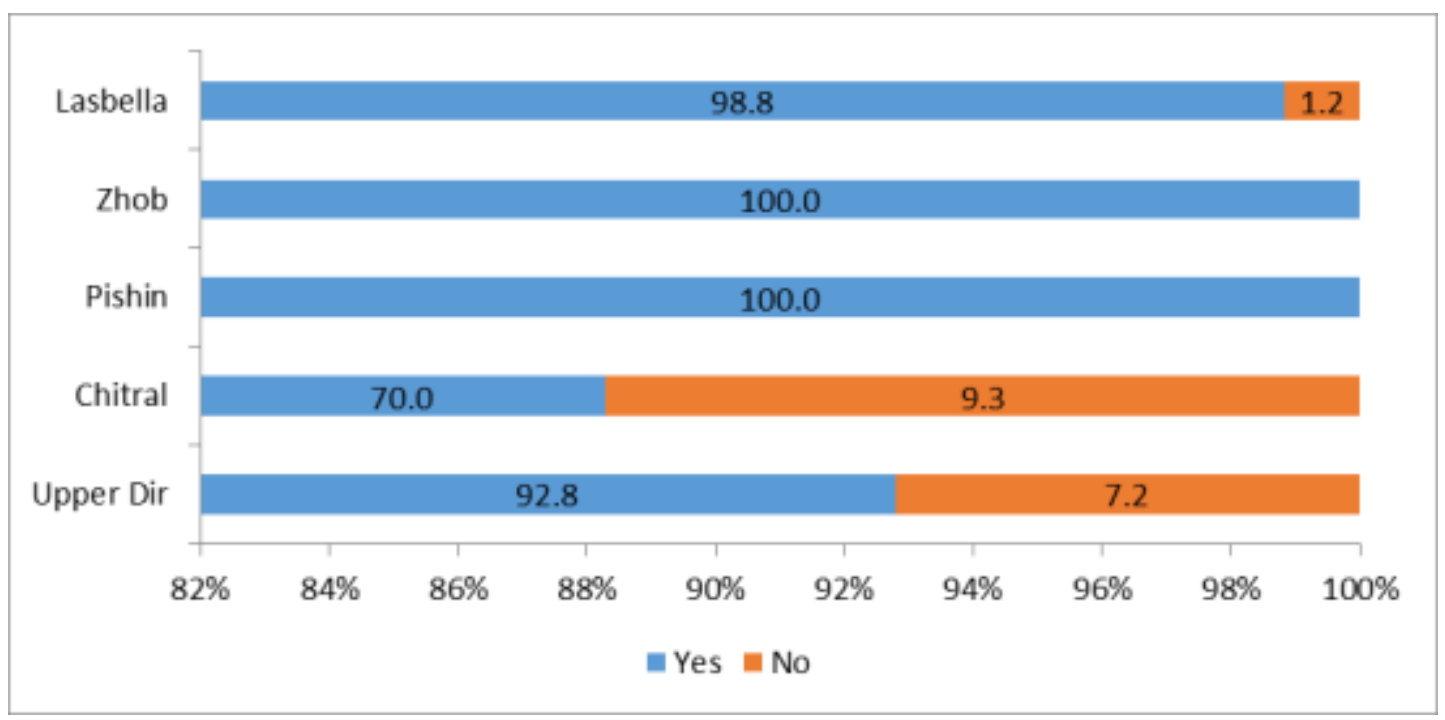

Figure 5. Increase in earnings

All the respondents in Zhob and Pishin told that their monthly earnings increased due to skills training (Figure 5). Majority of the skills training were based on technical and vocational skills training while trainings on asset management and regarding computer skills were also included. Respondents told that trainings should be of longer duration so that they can acquire maximum gain out of it. They also pointed out that the training contents should be revised and updated so that the latest information can be brought into the training. The training can produce further positive results by focusing more on providing practical knowledge along with theoretical contents.

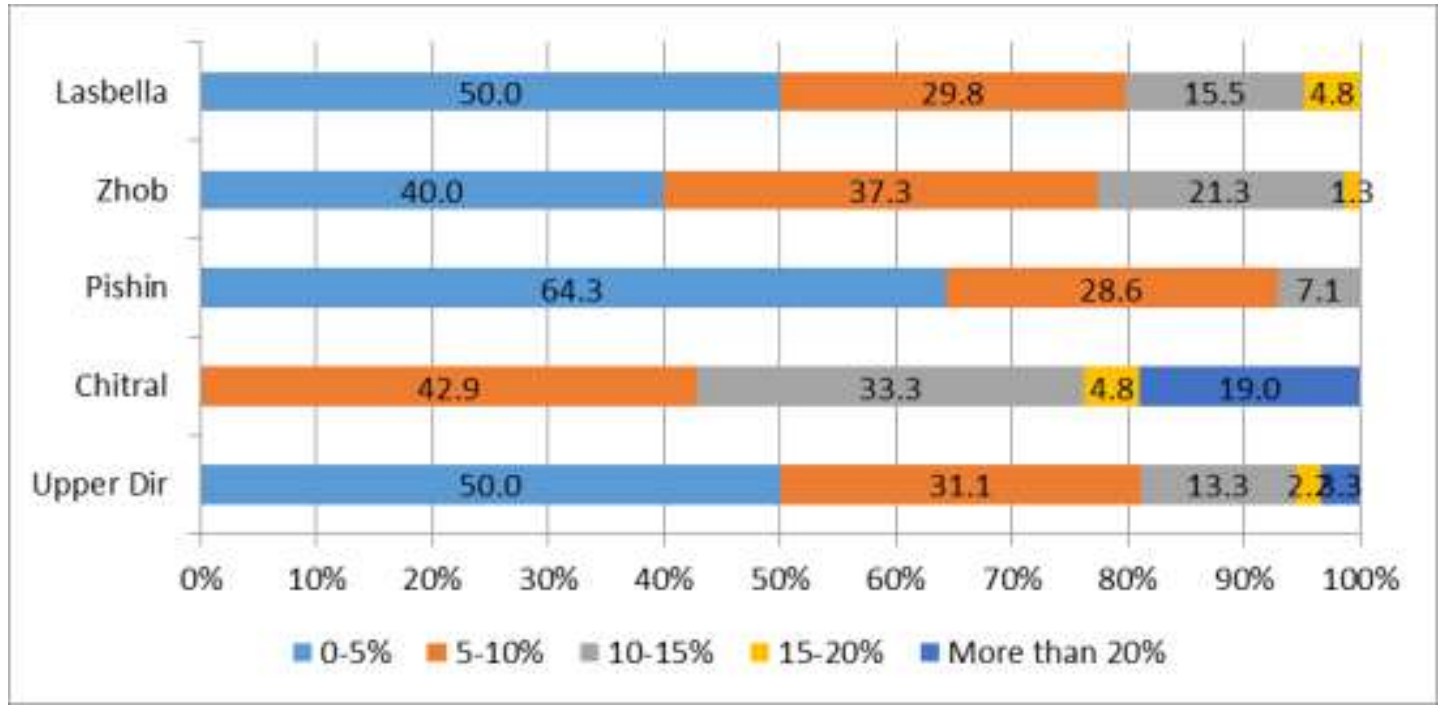

Figure 6. Percentage increase in monthly earnings

64.3\% respondents in Pishin reported that there earnings increased around $0-5 \%$ after the skills training (Figure 6). 42.9\% respondents in Chitral said that there earnings increased by around $5-10 \%$ while 19\% respondents in Chitral said that there earnings increased by more than $20 \%$. 


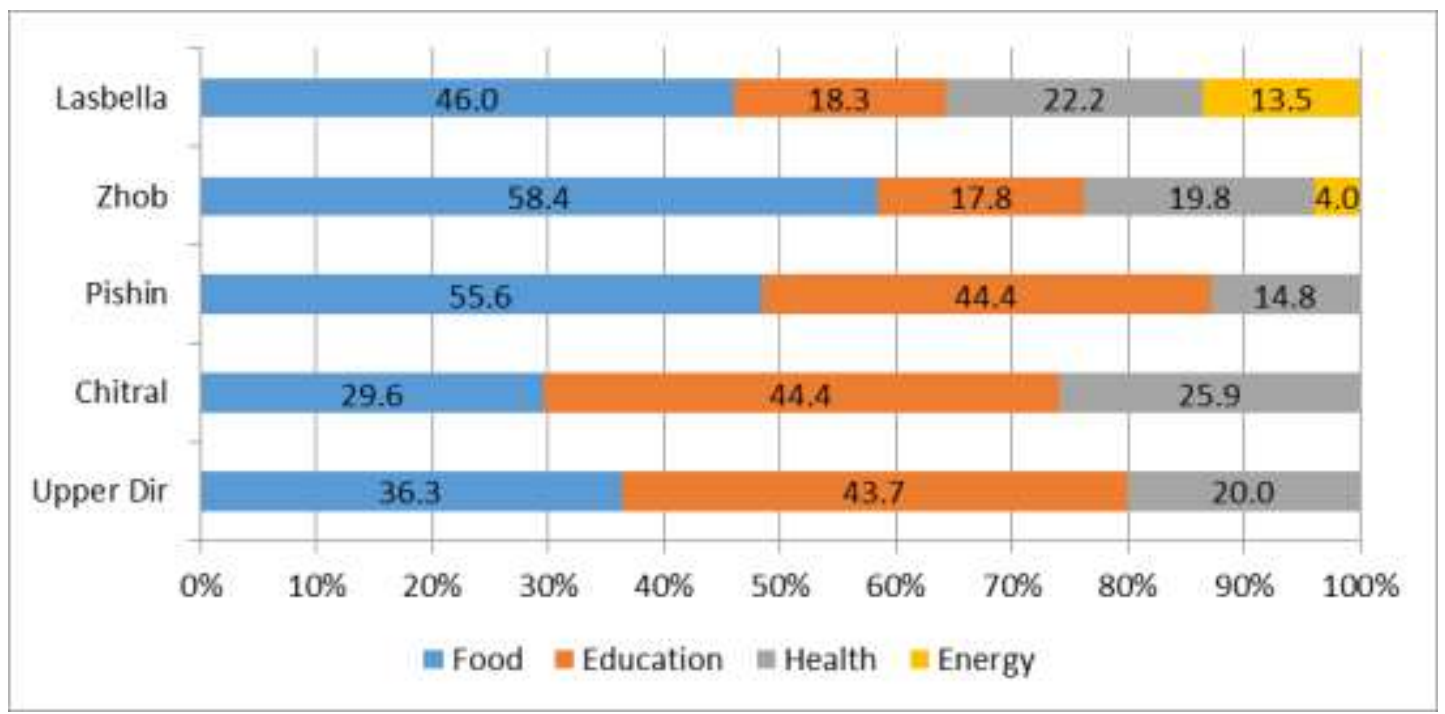

Figure 7. Spending of increased earnings

Most of the respondents in all districts were spending the increased earnings on food items (Figure 7). 58.4\% respondents in Zhob and 55.6\% in Pishin stated that they are spending the earnings on buying food items for their families

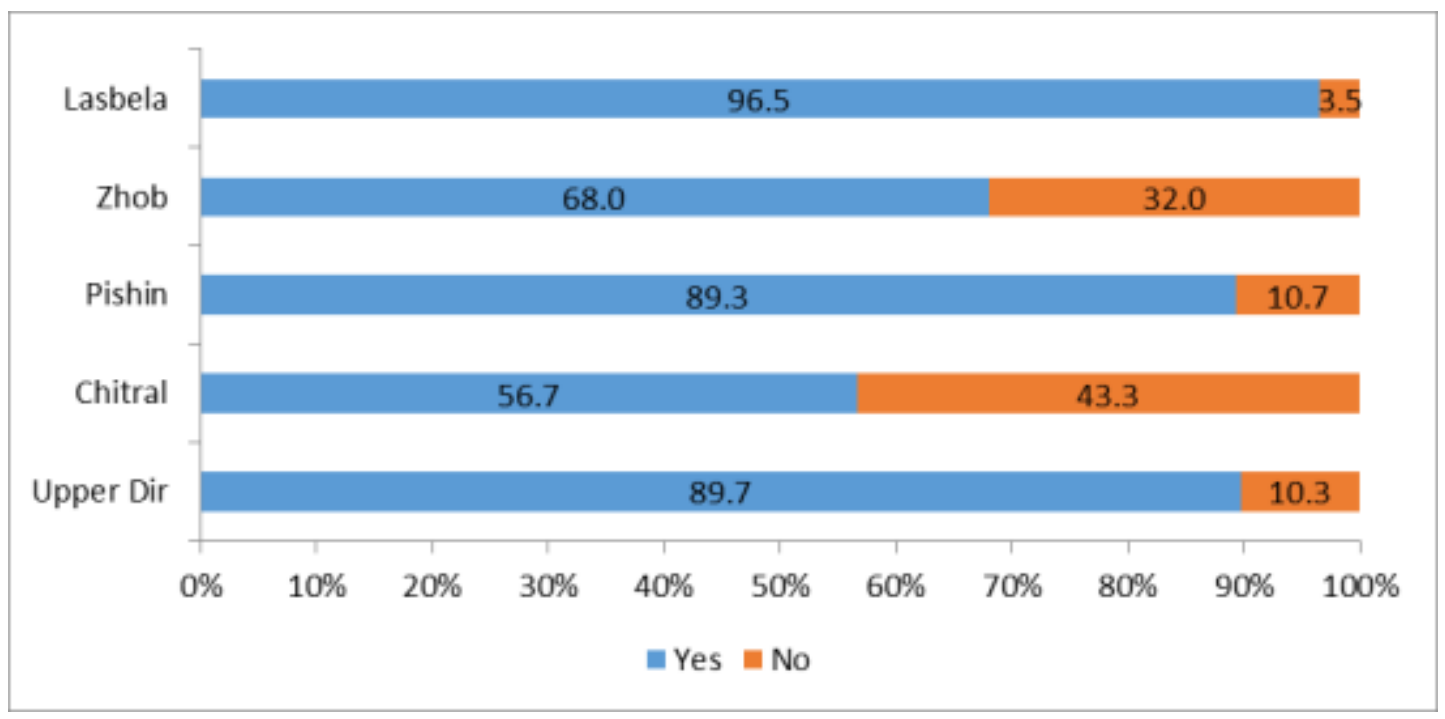

Figure 8. Increase in Women Empowerment

96.5\% respondents in Lasbela pointed out that the training has helped in increasing the women empowerment (Figure 8). Most of the women acquired vocational skills and asset management training. Majority of the respondents in other districts also stated that women empowerment has increased due to skills training. This is due to skill development based upon received training which helped in engaging them in economic activities. Due to cultural issues, women are not allowed to work outside their home but now they are working from home and earning for their families. That is also cited as one of the major issues in lower social enterprises development among the women as compared to men in Pakistan (2017). Women told that the involvement in economic activities also helped in increasing the decision making power within the household. One another positive outcome of increase in family earnings is that it increases the likelihood of female education which is beneficial for spreading awareness among communities (Ahmed and Zeshan, 2014). 


\section{Conclusion}

Social safety nets are significant for providing relief to poor households and also for graduating them out of poverty. Ehsaas is the major programme in this regard which has provided conditional and unconditional cash transfers to millions of households. Government of Pakistan recently launched Ehsaas programme under which 'Ehsaas Kafaalat' and Ehsaas Amdan' programmes are major programmes to support the poor households and uplift them out of poverty. These are newly targeted programmes which will improve the economic conditions of poor families through cash transfers and asset provision. Vocational training and interest free loans are also part of the programmes through which self-employment will be promoted.

The poverty has increased over the time period and in these circumstances, social protection programmes like the above mentioned have gained more significance. COVID-19 has further deteriorated the economic conditions as the economic activities are reduced and the employment of millions of workers is at stake (Javed, 2020b). Unforeseen shocks has affected Pakistan's economy in the past as financial crisis increases the poverty and consumer prices while it decreases the wages in Pakistan (Ahmed and Donoghue, 2010). The government has provided special relief to poor masses through cash transfer, however the provision of livelihood opportunities are more important. This is why the Livelihood Enhancement and Protection programme is important in providing earning prospects for the poor households through asset provision and skills training. Services sector hold major share in GDP of Pakistan.

The study provides lessons for Ehsaas programme and examines how a recent skills and asset provision interventions helped the communities. The survey of beneficiaries in Khyber Pakhtunkhawa and Balochistan indicate that the LEP programme has improved the livelihoods of poor households. On one hand, asset provision is helping in increasing the monthly earnings while on the other hand, asset base is also increasing as households are creating further asset on the basis of provided asset. It was suggested from the beneficiaries that in case of livestock asset, healthcare facilities should be provided for livestock including medication and checkup of animals to avoid any disease spread so that any injury or loss of asset can be avoided. This is because the Foot and Mouth Disease (FMD) is major disease which affects the animal's health and reduces the earnings of the asset holder (Javed, 2019).

Vocational and skills trainings are beneficial in skill development among the beneficiaries while they are also assisting in promoting women empowerment. E-commerce growth in Pakistan has opened a new window of opportunity and with attention of government millions of workers can be adjusted in the sector (Javed, 2020c) especially after Covid-19 scenario as the pandemic has promoted the need of workers having digital skills. Information and Communication (ICT) technology sector is another sector which has created many opportunities especially for youth and the skills training in the area can be beneficial for youth (Javed, 2019). The increase in earnings has also helped in ensuring better food and nutrition level of the households. Large scale seed-grant program and localized vocational training programs specifically for youth in the informal sector can be more helpful in promoting self-employment (Anam et al. 2016). Also the provisions of basic skills to youth encourage them towards self-employment (Javed, 2020d). Poverty reduction programmes should be devised according to the local poverty statistics and requirements. This will bring forth more positive results as compared to uniform policies for all regions. Rural poverty is more prevalent as compared to urban areas, so the more focus of the poverty alleviation strategies should be on rural areas. Weber and Duncan (2004) pointed out that due to 
difference in personal characteristics of population in rural and urban areas, it is difficult for social policy measures to move single mothers in rural areas into economic activity and get them out of poverty. Another link that is missing from the social safety nets is the inclusion of informal workers which are more than $50 \%$ of the total labor force (ShuHong et al. 2017). Especially in COVID-19 scenario when the millions of workers from informal sector are facing vulnerable employment situation, it is required to initiate efficient mechanism for addressing their grievances. The government should also focus on internal migrants particularly rural-rural migrants as they belong to the poorest income group and social safety nets are critical for them (Sadia et al. 2017). Although both cash transfers and asset transfers have their own advantages for the poor households, however asset provision is more beneficial in helping the vulnerable households to graduate them out of poverty level. However, it is required to ensure the quality of asset as in the case of livestock, it requires continues care and attention which poor households may not afford. Government should provide free vaccination and medical inspection of livestock asset to provide further assistance. Similarly training contents and frequency of trainings should be revised according to the regional requirements.

The government should also address any legislative gaps in the provision of social safety nets for which more focus on human rights instead of programs can be helpful (Manzoor et al. 2016). Budgeting of social safety nets should be more gender-responsive in order to reduce gender disparity (Tabassum et al. 2019). Furthermore, grievance redresses mechanism is required to bridge the trust gap among government and communities (Abbas and Ahmed, 2016). This can be done through involving civil society organizations which can introduce innovative methods for community mobilization. Also the service delivery can be improved through adopting technology in public organizations (Javed, 2020e).

\section{References}

Abbas, M. H., \& Ahmed, V. (2016). Challenges to social accountability and service delivery in pakistan. Social Change, 46(4), 560-582.

ADB. (2002). Poverty in Pakistan: Issues, causes and institutional response. Asian Development Bank.

Ahmed V., and Donoghue, C. (2010). Case Study: Global economic crisis and poverty in Pakistan. International Journal of Microsimulation (2010) 3(1) 127-129.

Ahmed, A., and Zeshan, M. (2014). An analysis of the social impact of the stipend program for secondary school girls of Khyber Pakhtunkhwa. Education Research for Policy and Practice (2014) 13:129-143.

Ahmed, A., Rabbani, M., Sulaiman, M., and Das, N. (2009). The impact of asset transfer on livelihoods of the ultra-poor in Bangladesh. Research Monograph Series No. 39.

Ahmed, V., and Javed, A. (2016). National study on agriculture investment in Pakistan. Working Paper No. 157, Sustainable Development Policy Institute.

Ashraf, M. A. (2017). Poverty and its Alleviation: The case of Pakistan', in G. Staicu (ed.), Poverty, Inequality and Policy, IntechOpen

Babayo Sule, \& Usman Sambo. (2020). Poverty in Gombe State: Causes, Manifestations and Strategies of Alleviation. Britain International of Humanities and Social Sciences (BIoHS) Journal, 2(3), 706-720.

Carter, M.R. and May, J. (2001). One kind of freedom: poverty dynamics in post-apartheid South Africa. World Development, 29 (12), pp. 1987-2006.

Cecchini, S., \& Madariaga, A. (2011). Conditional cash transfer programmes: The recent experience in Latin America and the Caribbean. Chile: Economic Commission for Latin America and the Caribbean. 
Fiszbein, A, Schady, N., Ferreira, F. H.G., Grosh, M., Keleher, N., Olinto, P., \& Skoufias, E. (2009). Conditional cash transfers: reducing present and future poverty (English). Washington, DC: World Bank.

Fultz, E., \& Francis, J. (2013). Cash transfer programmes, poverty reduction and empowerment of women: A comparative analysis. Experiences from Brazil, Chile, India, Mexico and South Africa. Geneva: International Labour Office.

Haque, N., Ahmed, V., and Sana, S. (2011). Reforms for competitive markets in Pakistan. Munich Personal RePEc Archive.

Hoddinott J. (2008). Social safety nets and productivity enhancing investments in agriculture. Paper prepared for the international conference on Convergence between social services provision and productivity enhancing investments. Pietermaritzburg, South Africa.

Holmes, R., \& Jones, N. (2013). Gender and social protection in the developing world, beyond mothers and safety nets. London: Zed Books.

Ishfaq, Sadia; Ahmed, Vaqar; Hassan, Danish; Javed, Asif. (2017). Internal Migration and Labour Mobility in Pakistan. Sustainable Development Policy Institute.

İşleyen, Şakir, \& Amir Khaleel Hassoo. (2020). The Impact of the University in Increasing the Book Reading on Students: Case Study Soran University. SIASAT, 5(4), 51-58. https://doi.org/10.33258/siasat.v5i4.70

Javed, A. (2020a). Impact of COVID-19 on Pakistan's services sector. Jurnal Inovasi Ekonomi, Vol. 5, No. 3

Javed A (2020b). Economic Impact of Coronavirus and Revival Measures: Way Forward for Pakistan. Policy Review, Sustainable Development Policy Institute (SDPI)

Javed A. (2020c). Prospects and Problems for E-commerce in Pakistan. Asian Journal of Economics, Finance and Management, Vol. 2, Issue 4

Javed A. (2020d). Youth Development in Pakistan: A Provincial Analysis" Journal of Development, Policy Research \& Practice, Vols. 3 \& 4, pp. 117-139

Javed, A. (2020e). The Scope of Information and Communication Technology Enabled Services in Promoting Pakistan Economy. Asian Journal of Economics, Finance and Management, Vol. 2, Issue 4.

Javed, A. (2019). Pakistan's Agriculture Trade with South Asia. Munich Personal RePec Archive (MPRA), Paper No. 95729.

Javed, A., 2019. South Asia's Services Trade: Barriers and Prospects for Integration. International Journal of Management, Accounting and Economics Vol. 6, No. 10.

Khan, A. (2013). Institutional Mapping Study of Social Protection Schemes in the Province of Khyber Pakhtunkhwa, ILO Country office for Pakistan, Islamabad.

Khan, Anam; Javed, Asif; Batool, Samavia; Hussain, Fazal; Mahmood, Hamid; Ahmed, Vaqar. (2016). The role of youth in sustainable development: Perspectives from South Asia. Sustainable Development Policy Institute.

Krishna, A., Poghosyan, M., and Das, N. (2014). How much can asset transfers help the poorest? Evaluating the results of brac's ultra-poor programme (2002-2008). The Journal of Development Studies, 48:2, 254-267.

Korea, M, D. (2020). Educational Counseling Programs for Students with Disabilities during the Pandemic. Budapest International Research and Critics Institute.

Manzoor, R., Toru, S., and Ahmed, V. (2016). Legislative Gaps in Implementation of Healthrelated Millennium Development Goals: a case study from Pakistan. Journal of the Pakistan Medical Association.

McKenzie, D. J., \& Woodruff, C. (2006). Do entry costs provide an empirical basis for poverty traps? Evidence from Mexican microenterprises. Economic Development and CulturalChange, 55(1), 3-42. 
Nasim, A. (2014). Fiscal Space for Social Protection in Pakistan. Institute of Development and Economic Alternatives, Policy working paper no. 01-14.

OPM (2020). Benazir Income Support Programme: Evaluation Report. Oxford Policy Management.

OPM. (2016). Impact report BISP programmes. Oxford Policy Management.

PPAF. (2014). Investigate study on livelihood projects. Pakistan Poverty Alleviation Fund, Final Report, November 2014.

Richardson, M., Tsui, J., Nazir, A., Ahmed, V. (2017). Activist to entrepreneur: The role of social enterprise in supporting women's empowerment in Pakistan. Sustainable Development Policy Institute.

Selvaraj, A. (2011). An overview of poverty eradication programmes in India. Economic Affair: v.56 n.4 p. 335-343.

ShuHong, Y., Din, M. and Ranjha, K. (2017). Social protection schemes in Pakistan: an assessment of existing program. Academic Journal of Business, Administration, Law and Social Sciences, Vol. 3, No. 2.

Tabassum, R., Manzoor, R., Ahmed, V., Zahid, J., Waleed, I., and Saleem, M. (2019). Integrating Gender into Educational Planning and Budgeting. Sustainable Development Policy Institute, Working Paper No. 171.

Wallenborn, M. (2009). Skills development for poverty reduction (SDPR): The case of Tajikistan. International Journal of Education Development.

Weber, B., Edwards, M., and Duncan, G. (2004). Single mother work and poverty under welfare reform: Are policy impacts different in rural areas? Eastern Economic Journal, 30(1):31-51. 